\title{
A Logical Approach to Modal Verbs 3. "Must"
}

\author{
Attila IMRE \\ Department of Applied Linguistics \\ Faculty of Technical and Human Sciences, Târgu-Mureş \\ Sapientia Hungarian University of Transylvania \\ attilaimre@ms.sapientia.ro
}

\begin{abstract}
The article aims at a logical approach to discussing must, organized around the core meaning of necessity, split into epistemic (logical necessity) and deontic necessity (obligation). After discussing must as a central modal auxiliary, we present various meanings of must, relying on authoritative sources published for international (English), Hungarian, and Romanian students. Possible issues of teaching must are also dealt with, supported by data from a popular TV series containing modal verbs. The conclusion discusses the importance and relativity of a number of occurrences, trying to offer a possible teaching option for modals stemming from practice.
\end{abstract}

Keywords: modality, central modal, epistemic, deontic, teaching modal verbs

\section{Introduction}

It is common knowledge that the English modal verbs are usually discussed separately from the English verbs due to their "special" form and meaning. However, we tend to think that the "basic structure of the English verb is not particularly complicated" and is not "full of exceptions" (Lewis 1986: 7). We have argued (Imre 2008: 8-11) that - functionally viewed - we may distinguish four types of verbs:

1. strong (S): I. and II. forms of be in indicative mood, when used without other verbs in a sentence: am, are, is, was, were;

2. auxiliary (A): do (does, did), have (has, had), be (am, are, is, was, were), followed by another verb in I.-ing or III. form;

3. modal (M): can, could, may, might, must, shall, should, will, would (central modals);

4. weak (W): all the other verbs. 
The possible combination of these verbs is highly important as the relatively fixed English word order leads to specific verb combinations: only $S$ or W verbs may be "alone" in a sentence (W only in affirmative, $S$ in affirmative, interrogative, and negative), while verb combinations lead to various tenses or passive structures:

- AW: Winnie-the-Pooh is enjoying a jar of honey.

- MAW: Little Red Riding Hood may have taken a different path.

- MAAW: John Doe could have been killed in the jungle.

By analysing these "MAW" properties, linguists have drawn the conclusion that whenever a modal verb is implied in a string of verbs, it is always first, and there is no co-occurrence among them (Quirk, Greenbaum, Leech, and Svartvik 1980: 75). This way, we have "marginal" modals, such as have to, which carries modal meanings, but it is formally an "outsider" as it may be preceded by a central modal (You will have to explain this.). Interestingly, modals take over certain auxiliary functions as well such as forming the interrogative, negative, or question tag (Lewis 1986: 57-58); so, we can refer to them as "operators". Modals have also been referred to as modal auxiliaries, defective modal verbs (lacking the majority of forms), anomalous or special finites, mood formers (Bădescu 1984: 383), and even secondary auxiliaries (Greenbaum 1996: 153), even if the term is not very logical as they are always "first" in a string of verbs - mentioned later in the same Greenbaum (1996: 260-266).

They may express the speaker's "personal judgment of the non-temporal features of an action" (Lewis 1986: 138) or the "attitude of the speaker" (Palmer 1990: 2) in the form of specific concepts (possibility, necessity, politeness, etc.); thus, an initial formal division is necessary (Quirk, Greenbaum, Leech, and Svartvik 1985: 3-6; Swan 2005: 325-327), leading to:

1. central or core modals: can, could, may, might, shall, should, will, would, must;

2. marginal, peripheral, quasi- or semi-modals: dare, need, ought to, used to; have to and be to may be listed here;

3. semi-auxiliary (modal) verbs and constructions are formally "outside the [modal] system" (Palmer 1990: 3), such as be able to or be going to;

4. modal idioms: had better, would rather, would sooner, have got to, could possibly, may well (Quirk et al. 1985: 137);

5. catenative constructions: appear to, come to, fail to, manage to, seem to, tend to, etc.

In the present article, we deal with must - so, it is important to briefly discuss the features of central modals. 


\section{MUST as a central modal verb}

As categories tend to be fuzzy in the majority of cases (cf. Eleanor Rosch's prototype theory), even central modals lack minor features. For instance, can has no perfective construction in the affirmative, may is not used in present negative constructions, and must has no distinctive "past" form.

However, must is a central modal, having a single form for all persons and numbers, whatever the time reference, violating the rule of "concord" between the subject and predicate (Quirk et al. 1985: 149). It takes over major auxiliary functions (cf. the NICE properties, Huddleston 1976: 333), such as interrogation or question tags (although not always), ${ }^{1}$ while negation is more complicated, especially in the case of must. Furthermore, must is always followed by either the short infinitive (I. verb form) or a perfect infinitive construction (must have + III. verb form): must see, must have known.

As a full and systematic approach is near-impossible, we will try to follow a "personalized" approach to must, accepting that modals represent "one of the most complicated problems of the English verb" (Lewis 1986: 99), dedicating a special focus on its form (affirmative, interrogative, and negative) and meaning (past, present, and future reference).

It has been stated that the time reference of modals is "now" or, more precisely, when the speaker's utterance is voiced, paraphrased as "in the present circumstances, my judgment is that it is possible / necessary / desirable that ..." (Lewis 1986: 102), so their meaning is context-based, which is at least the length of an entire clause or sentence, if not a paragraph.

Past and future reference is possible with had to and will have to:

When I was four, I had to go to the kindergarten.

If you want to stay alive, you will have to drink water regularly.

Sometimes, the special meaning of modal verbs is reflected even in question tags, breaking the "standard" positive - negative, negative - positive rule:

John must not fail, mustn't he?

Must is usually replaced by the proper form of have to (had to) in sequence of tenses and reported speech when past reference is needed; however, this is not compulsory as it may remain must after reporting verbs for prohibition or logical deduction (Gălățeanu-Fârnoagă 1995: 236), but it can report present tense "in any of its uses" (Palmer 1990: 121):

John knew he must not contradict the colonel during the briefing.

She confessed that she must have been tired enough not to see the danger.

Jane said that John must enter the bushes first.

Have to may be a viable replacement for must in future (will have to) or past (had to):

1 Meaning-based exception: You must obey the coach, don't you? 
Whether you like it or not, you will have to face your fears. (reluctance)

When he was in the army, he had to follow orders, but he didn't have to report regularly.

\section{Meanings of MUST}

From the outset, we should accept that "difference of form implies difference of meaning (Lewis 1986: 26), and the distinction between must and have to is more than central and marginal modal, and there is a reason why they differ in form and use.

However, it may be considered the most interesting verb, having two options for constructing the negative (formal and meaning-based negatives), leading to two separate meanings (expressed by mustn't and don't have to/needn't).

By and large (exceptions mentioned separately), must may be followed by I. verb form (referring to present, past, and future); ${ }^{2}$ a clearly past reference derives from must + have + III. verb form or had to, while future reference from will have to. Yet, it is more often connected to future due to its uses (Palmer 1990: 121).

\subsection{Epistemic necessity - logical deduction, possibility}

Logical deductions or plausible events are felt to be very sure by the speaker (certainty), which may often be based on "world knowledge":

The Does must be very tired after having fought in the jungle for 16 hours.

The Does must have been very tired after a 16 hours' fight in the jungle.

What goes up must come down. (proverb)

This must be the entrance, as there's no other door.

That must have been the entrance, as we couldn't find any other door.

You must have heard the news, everybody's talking about the Does.

The negative synonym for must is can’t (Vince \& Emmerson 2003: 92):

Jane can't be a nice person. (I'm sure that she isn't.)

Certainty may be emphasized by an introductory surely, resulting in exclamation (Vince 2009: 73):

Surely you must have spent all the money!

Surely you can't have seen a ghost!

However, logical deductions may be less conclusive, being closer to assumption, presupposition, possibility, especially in "estimating statements" (Zdrenghea \& Greere 1999: 261):

2 As must has a single form, its context offers a guide whether it refers to past, present, or future; thus, a clear past or future reference (Bădescu 1984: 425) is needed: when I was a child (past), next week (future), etc. However, its use in past context is extremely rare (Levițchi 1971: 153). 
Jane must be a nice person; I have heard so much about her.

Com'on, you must know the answer, you know everything!

John must be older than Jane. (an educated guess)

When the speaker feels lack of logic or reason, irritation may take the form of (indirect, rhetorical) question with must (Budai 2007: 217):

Why must you always be late for work?

I don't understand why you must always be late for work.

Conclusions may be associated with must as they are based on circumstances, being characterized by the speaker's confidence (Palmer 1990: 53):

You must follow the orders at all costs. (similar to an obligation)

Bill Gates must be rich enough to support education worldwide. (characteristic)

Logical necessity is typically connected to scientific, technical descriptions:

In order to obtain the best results, we must use an algorithm.

We must face our destiny. (inevitable things, cf. Palmer 1990: 130)

\subsection{Deontic necessity - obligation}

Must may express internal obligation, personal feelings (Murphy 1994: 62); if it is "imposed by the speaker", it means that the speaker considers it important, justified, etc. (Bădescu 1984: 425):

I must stop daydreaming. ( $\sim$ will have to, $\sim$ be obliged to, $\sim$ be forced to)

After a while, I realized I must/had to stop daydreaming.

However, in the majority of cases, internal or external obligation is not strictly separated. When it is important, external obligation is expressed by have to. In case the type of obligation is not clear, both versions are acceptable:

Jane must help John. Jane has to help John.

Obligation may derive from impersonal orders (Magyarics 1997: 254), obeying the law, rules and regulations (Budai 2007: 214), interdiction, prohibition (Bădescu 1984: 426), duties or notices posted in public places (Coe, Harrison, and Paterson 2006: 144), imposed by external authorities (Gălățeanu-Fârnoagă 1995: 231):

Students must keep silence during exams.

Everybody must work to bring home the bacon. (neutral, general necessity)

Producers must comply with the regulations.

Visitors must not feed the animals.

Rules must be obeyed. (passive voice)

The Does must fly to Burma at once. They must not delay.

Present necessity may lead to either near-future fulfilment or never to be done. As such, must is not an automatic indicator of will (Preda 1962: 327):

Children must listen to their parents. $\neq$ Children will listen to their parents. 
Less strict necessity or obligation is possible with need (replacing both must and have to):

You must think about that. You have to think about that. You need to think about that.

The absence of obligation or necessity is expressed with needn't or don't/ didn't/won't have to, and even am not to, was not to (especially for past and future reference):

You must think about that. $\leftarrow \rightarrow$ You don't have to think about that.

John won't have to worry about Jane.

John was not to take hostages. (frequently used, cf. Preda 1962: 329)

There are various alternative constructions expressing deontic must (Levițchi 1971: 154, Preda 1962: 329):

- positive form: be compelled to, be forced to, be obliged to:

John was forced to retreat due to the heavy artillery fire.

- negative form: am/are/is not to, be not allowed to, be not permitted to.

Jane is not allowed to share details of the mission with anyone.

\subsection{Other meanings}

Must may express reproach, hidden admonition, in which case it is stronger than should; past unfulfilled actions resulting in something negative (failure, remorse, etc.):

All of you must have worked harder. (That's why your wages are lower than expected.)

Jane must have helped John. (Because she failed to, John is hospitalized.)

Emphatic advice, suggestion, persuasion, "casual” invitation (Gălăteanu-Fârnoagă 1995: 230), or request, which hardly leave room for contradiction, being "almost an imperative” (Palmer 1990: 73) may also be associated with must:

You must join me to celebrate my birthday.

In effect, this is similar to emphatic imperatives starting with do:

Do join me to celebrate my birthday.

This is possible because the speaker has certain authority to lay an obligation; yet it is polite to insist on offering something to the benefit of the addressee, and it is equally polite to refuse it. However, it is equally true that not all emphatic invitations or polite offers are to be taken seriously (Palmer 1990: 194).

When must is used with wh-words, it may easily express irritation (for habits, repeated events):

Why must I accept that I can't join you to the beach?

Whenever I start eating, you must show up... 
However, proper gesture or intonation may turn it into ironical or humorous remarks. Irritation may be due to rather indiscreet questions, to which a specific stock phrase (Budai 2007: 217) is the answer:

If you must know, the Does are in Burma.

On the other hand, irritation may be softened and turned into involuntary (forced) acceptance or resignation when must is combined with if (Budai 2007: 217):

If you must accept the challenge, do it bravely.

If I must keep quiet, then why do you keep shouting?

Interestingly, the obligation may be imposed on the speaker ( $I$ or we), in which case the sense is weakened (Palmer 1990: 73-74):

I must say that I truly admire what Jane has accomplished so far.

Other verbs associated with must in this sense are: admit, ask, be honest, concede, confess, mention, realize, reiterate, remember, understand - and all of them express that the speaker effectively admits the action.

\subsection{Must in negative and interrogative structures}

The standard "perfect" antonym of words is their form headed by not (e.g. orange $\leftarrow \rightarrow$ not orange, like $\leftarrow \rightarrow$ not like). However, must is an exception to this rule, having both a grammatical negation (mustn't) and two meaning-based negatives (don't have to, needn't).

Grammatical negation is constructed by must + not (or mustn't), used for strong prohibition:

You must listen to me. (It is imperative to focus on me.)

You mustn't listen to politicians. (It is strictly forbidden to listen to them.)

The negation expresses "necessity for something not to be done" (Palmer 1990: 34), and mustn't refers to the entire proposition.

Alternatives for strong prohibition are:

You shall not leave the room without my permission. (rules)

John can't visit Jane any time he wants. (personal remarks)

Meaning-based negation of must is expressed by don't/didn't/won't have to and needn't, used for the absence of obligation or necessity (Levițchi 1971: 232) in past, present, or future:

John doesn't have to explain the colonel what happened.

An alternative for "unnecessary" is needn't:

John needn't explain anything.

The past reference for the meaning-based negative must is colourful:

Snipers must have stayed alert all night. (But they didn't.)

Snipers had to stay alert all night. (So they did.)

John needn't have sharpened his knife for two hours. (But he did.) 
John didn't have to sharpen his knife. (So he didn't.)

Interrogative forms starting with must may express at least two major meanings:

- standard question, not sure whether the answer is going to be yes or no:

Must I answer the questions of the press? No, you needn't. ${ }^{3}$

- nuisance, annoyance, irritation:

Must you always ask me for money?

However, when the person is hoping for a negative answer, need is used.

\section{Teaching MUST}

Teaching modal verbs is an eternal challenge, but this does not mean that there are no successful options, starting from theory followed by practice or concepts (speech acts) first and then exemplified with modal uses. A justified question is when to teach them, as describing them involves verbs and tenses. As modals may easily be included in conditional, hypothetical constructions, as well as passive voice and reported speech, we tend to think that it is more successful to tackle modals after these categories have been discussed.

The what of modal verbs includes their form (affirmative, interrogative, and negative), knowing that the interrogative or negative might be more important from the point of view of meaning than others; for instance, the interrogative need hopes for a negative answer, while the negation of must takes two separate paths.

A different alternative from "theory-first, practice-later" might present learners well-chosen samples, enabling them to formulate possible rules regarding the form and meaning of modals. In this respect, we can recommend a set of quotes and proverbs with must as a lead-in activity:

We must, indeed, all hang together or, most assuredly, we shall all hang separately.

(Benjamin Franklin, arguably one of the most notable statements with must)

We are all born ignorant, but one must work hard to remain stupid. (Benjamin Franklin)

You must be the change you wish to see in the world. (Mahatma Gandhi) It is a truth universally acknowledged, that a single man in possession of a good fortune, must be in want of a wife. (Jane Austen: Pride and Prejudice)

You must do the things you think you cannot do. (Eleanor Roosevelt) You must stay drunk on writing so reality cannot destroy you. (Ray Bradbury)

3 In this case, needn't negates the modality (Palmer 1990: 38). 
A journey of a thousand miles must begin with a single step. (Lao Tzu) You must be joking. (idiomatic expression, Br. E.)

You gotta be kidding. (idiomatic expression, Am. E.)

The washing machine is a must-have in each house. (non-modal use of must)

Learners may wish to discuss and translate them, but it is obvious that this must be completed with "real-life" situations. TV series may be motivating enough to watch and check modal verb occurrences and frequency. One of our favourites is Castle, ${ }^{4}$ having 8 seasons with 173 episodes (combined) of at least 40 minutes' length each; that is, 6,920 minutes, or more than 115 hours. It may be shocking to realize that the first season of 10 episodes alone contains a multitude of modal uses, detailed in the table below:

Table 1. Modal occurrences in Castle

\begin{tabular}{|c|c|c|c|c|c|c|c|}
\hline MODAL & NR & $\%$ & MODAL & & & & \\
\hline CAN & 226 & 18.56 & 'll & 103 & \multirow{3}{*}{182} & 8.46 & \multirow{3}{*}{14.94} \\
\hline COULD & 128 & 10.51 & WILL(ING) & 65 & & 5.34 & \\
\hline be able to & 11 & 0.90 & WON'T & 14 & & 1.15 & \\
\hline capable & 1 & 0.08 & 'd & 107 & \multirow{2}{*}{310} & 8.78 & \multirow{2}{*}{25.45} \\
\hline manage & 7 & 0.57 & WOULD & 203 & & 16.67 & \\
\hline succeed & 1 & 0.08 & SHALL & 1 & & 0.08 & \\
\hline MAY & 18 & 1.48 & SHOULD & 54 & & 4.43 & \\
\hline MIGHT & 39 & 3.20 & ought to & 2 & & 0.16 & \\
\hline allow & 1 & 0.08 & need* & 104 & & 8.54 & \\
\hline permission & 3 & 0.25 & dare* & 5 & & 0.41 & \\
\hline MUST & 34 & 2.79 & \multirow{2}{*}{ TOTAL } & \multirow{2}{*}{1218} & & \multirow{2}{*}{$100 \%$} & \\
\hline have/has/had to & 91 & 7.47 & & & & & \\
\hline
\end{tabular}

For teaching purposes, it is worth checking the instances of must: season 1 contains 34 sentences with must, out of which there are 32 affirmative sentences and 2 interrogative ones, both expressing annoyance:

Darling, must you always have to make a comment? Must you always eavesdrop? A further analysis shows that all instances of must followed by I. verb form refer to a present context (15 cases), and there are 17 cases of must have + III. verb form expressing past:

I can't imagine how they must feel. Poor kid must have been a mess.

4 http://www.imdb.com/title/tt1219024/?ref_=fn_al_tt_1 - 26.02.2017. 
There are only 2 passive constructions with must, but one of them is continuous: Must be connected. Sales must be slipping.

Having in mind the theory associated with must, the most important question is the ratio of deontic and epistemic must; as past reference cannot be deontic (we cannot formulate an effective obligation for the past), we have checked that only 2 instances may express deontic must, although one of them is controversial:

A civilian, not a cop, must make the drop.

I'm sorry, detective, but you must know that information on a protected witness is confidential (deontic use possibly stemming from epistemic "world knowledge": a detective is trained to know that, and this is reiterated as a warning).

We can draw the conclusion that theory put into practice changes completely the balance, as logical necessity prevails by far. We would have expected to find instances of negative must (mustn't), but none were found in Season 1. However, the first season is a meagre $5.78 \%$ of the entire series; so, we searched for the occurrences of must in Season 2 (13.87\%) with the following results:

- 102 affirmative, 2 interrogative (both expressing annoyance), and 1 negative structure:

She must have not wanted to rock the boat.

- 66 perfective structures (must have + III.).

- 4 continuous structures: e.g. And she must be going through hell right now.

- 1 perfect continuous structure: Jessica must have been wearing this before she died.

- 4 conditional clauses containing must.

- 3 passive constructions.

- 4.375 occurrences of must/episode compared to 3.4 occurrences/episode from Season 1. This means that during the 1,360 minutes 139 instances of must were found; so, roughly every 10 minutes of video contains a must.

Depending on the learners' level, we should start with must + I. verb forms expressing logical necessity in affirmative, followed by interrogative and negative forms (introducing have to). The next stage may be the must have + III. form, passive and conditional constructions, completed with translation into the learners' native language.

It is clear that the higher the frequency, the more situations are possible for a particular modal verb to be used, but non-modal factors still have to be considered. Will, for instance, is a suitable modal to function as the future operator (a term which may be applied, by and large, to the majority of auxiliaries and modals, involved in forming the negation and interrogation, although "imported" from logic). Aarts' frequency table per million words (Aarts 2011: 280 ) shows that must has 472 spoken and 857 written occurrences, while mustn't has only 24 spoken and not a single written occurrence. Yet the target audience must be considered as, for instance, language exam students have different 
needs compared to translation and interpretation students, who - in our opinion - should be acquainted with all possible must instances in order to correctly render them in their native language.

\section{Conclusions}

As countless books and articles have been written on modality, we cannot claim that the present article brings too much novelty to the issue of modality and modal verbs. Nevertheless, the way we approach them tries to offer a new perspective of must, and hopefully a more logical one; however, due to constraints of space, the relationship between must, have to, and need is rather limited, although data suggest that have to (together with has to, had to, and will have to) outnumbers must by around 3:1.

Although the references come from authoritative native speaker authors (Cambridge and Oxford publications), they typically lack an important feature: why and how these modal verbs represent a problematic category for non-native speakers. This is why we extended our research to reputable Hungarian and Romanian publications, trying to summarize all relevant information regarding must.

We have seen that despite the extended theory of modals, practice is rather "biased" towards certain uses. Whether all uses are justified to be taught depends on the learner's study level, but in the case of translators and interpreters frequency is less relevant as one mistranslation or misinterpretation may result in complete distrust.

\section{References}

Aarts, B. 2011. Oxford modern English grammar. 1s $^{\text {st }}$ ed. Oxford-New York: Oxford University Press.

Alexander, L. G. 1988. Longman English grammar. Longman.

Bădescu, A. L. 1984. Gramatica limbii engleze. Bucharest: Editura Ştiințifică şi Enciclopedică.

Budai, L. 1994. English grammar - theory and practice. Budapest: Nemzeti Tankönyvkiadó.

2007. Élố angol nyelvtan. Rendszeres kontrasztív grammatika sok példával. Budapest: Osiris.

Carter, R.-McCarthy, M. 2006. Cambridge grammar of English: a comprehensive guide. Cambridge, England-New York: Cambridge University Press. 
Coe, N., Harrison, M., \& Paterson, K. (2006). Oxford Angol Nyelvtan. Magyarázatok - Gyakorlatok. Oxford: Oxford University Press.

Foley, M.-Hall, D. 2012. MyGrammarLab. Harlow, Essex: Pearson Longman.

Gălățeanu-Fârnoagă, G. 1995. Sinteze de gramatica engleză: Exerciții şi teste de evaluare. Bucharest: Cruso.

Greenbaum, S. 1996. The Oxford English grammar. $1^{\text {st }}$ ed. London: Clarendon Press. Harrison, M. 2004. Use of English. First Certificate skills. Oxford: Oxford University Press.

Huddleston, R. 1976. Some theoretical issues in the description of the English verb. Lingua 40(4): 331-383. https://doi.org/10.1016/0024-3841(76)90084-X.

Huddleston, R.-Pullum, G. K. 2005. A student's introduction to English grammar. Cambridge, UK-New York: Cambridge University Press.

Imre, A. 2008. Logikus angol nyelvtan. Bucharest: Editura Didactică şi Pedagogică.

Levițchi, L. 1971. Gramatica limbii engleze. Bucharest: Editura Didactică şi Pedagogică.

Lewis, M. 1986. The English verb: an exploration of structure and meaning. Hove: Language Teaching Publications.

Magyarics, P. 1997. Gyakorlati angol nyelvtan. $2^{\text {nd }}$ ed. Budapest: Akkord \& Panem. Murphy, R. 1994. English grammar in use with answers. $2^{\text {nd }}$ ed. Cambridge: Cambridge University Press.

Murvai, O. 2001. Szematikai és pragmatikai kiegészítések a modalitás vizsgálatához. In: J. Petőfi S.-I. Szikszainé Nagy (eds), Grammatika - szövegnyelvészet szövegtan. Debrecen: Kossuth Egyetemi Kiadó. 59-69.

O'Connell, S. 1999. Focus on advanced English: C.A.E. for the revised exam. $1^{\text {st }}$ ed. Harlow: Longman.

Palmer, F. R. 1990. Modality and the English modals. London-New York: Longman. Preda, I. A. (1962). In: C. G. Sandulescu-L. Vianu (eds), Gramatica limbii engleze. Verbul I. Clasificări (1 ${ }^{\text {st }}$ ed., vol. 4: 265-380). Bucharest: Universitatea.

Quirk, R.-Greenbaum, S.-Leech, G.-Svartvik, J. 1980. Grammar of contemporary English. Longman.

1985. A comprehensive grammar of the English language. $2^{\text {nd }}$ ed. London-New York: Pearson Longman.

Swan, M. 2005. Practical English usage. $3^{\text {rd }}$ ed. Oxford: Oxford University Press.

Thomson, A. J.-Martinet, A. V. 1986. A practical English grammar. $4^{\text {th }}$ ed. Oxford: Oxford University Press.

Vince, M. 2009. Advanced language practice: student book pack with key. $4^{\text {th }}$ ed. Oxford: Macmillan Education.

Vince, M.-Emmerson, P. 2003. First Certificate language practice: with key. Oxford: Macmillan Education.

Zdrenghea, M. M.-Greere, A. L. 1999. A practical English grammar. Cluj-Napoca: Clusium. 